\title{
Development of Learning Media Based on Virtual RealityIn the Subject Object-Oriented Programming Improving Learning Outcomes of RPL Students at SMK Negeri 2 Bangkalan
}

\author{
Moh. Rochman Wahid Maulana', Supari Muslim², I Gusti Putu Asto \\ Buditjahjanto $^{3}$, Bagus Dwi Cahyono ${ }^{4}$ \\ State University of Surabaya \\ moh.maulana16070895014@mhs.unesa.com
}

\begin{abstract}
AbstractThe research objectives are: (1) analyzing the validity of virtual reality-based learning media on the subjects of object-oriented programming; (2) analyze the implementation of object-oriented programming learning using virtual reality-based learning media; (3) analyze the learning activities of Bangkalan Vocational High School 2 students on object oriented programming subjects using virtual reality based learning media; (4) analyze learning outcomes in the cognitive, affective, and psychomotor domains on object oriented programming subjects; and (5) analyze the response of students of SMK Negeri 2 Bangkalan to virtual reality-based learning media. Media development is done by using Research and Development (R \& D) which is validated by experts. The results of the study concluded that: (1) virtual reality-based learning media were declared valid with very good categories; (2) the implementation of virtual reality based learning media is categorized as good; (3) student learning activities in utilizing virtual reality based learning media are declared active.
\end{abstract}

Keywords: Learning media, R \& D, virtual reality, learning outcomes, and object-oriented programming, vocational students.

\section{INTRODUCTION}

Human life is never separated from the learning process. Since being born, a child learns how to crawl, walk and talk. The learning process takes place in many ways, both intentionally and unintentionally, and lasts throughout life to acquire new knowledge, understanding, skills and habits which manifest experience. The experience gained is the interaction between individuals and the environment as a learning resource Trianto, [1].Law No. 20 of 2003 concerning the National Education System, states that education is a conscious and planned effort to realize the learning atmosphere and learning process so that students actively develop their potential to have religious spiritual strength, selfcontrol, personality, intelligence, noble character, and the necessary skills himself, society, nation and country.Education is one form of manifestation of human culture that is dynamic and full of development Trianto, [1]. The development or change in the world of education goes hand in hand with the development of culture and technology. The development is expected to be able to provide improved education so that it can support the progress of the nation.Prawiradilaga,[2] explains that, the learning process as part of the life of the advanced community provides an opportunity for each individual to develop. For this reason, physical boundaries such as buildings, learning locations, teacher attendance are not absolutely necessary for the learning process. The progress and establishment of digital technology applied in the world of education facilitates and accelerates learning access including the delivery of teaching materials to be faster, easier, and affordable.Alwi,[3] explains that learning activities can be interpreted as all activities that will be carried out by students both outside and inside the school. 
Learning activities will become more intensive if done using technology including information technology. Information and communication technology is very influential on the development of education. According to Prawiradilaga,[2] that the world of education and training is affected by the digital technology and internet industry. This impact can be considered positive because it encourages various parties, educators, instructors, managers of educational organizations, and students to adapt to innovation and the global era. Adaptation to the environment can be done using technology called virtuality technology.The definition of virtual reality is a technology that allows users to interact with a computer-simulated environment. An actual environment that is imitated or really - really only exists in one's imagination Psotka, [4]. The media used in schools are only power point media and there is no simulation in the form of virtual reality based learning media. Virtual reality is the delivery of electronic learning materials to mobile computing devices so that they can be accessed anywhere and anytime. Thus students can better understand in a simulation of the material. The concept of learning using virtual reality provides many benefits, both for teachers and students.Therefore, the use of virtual reality strongly supports the learning process carried out in the classroom. The subject matter given in the class is usually sourced from textbooks or modules. The material can be supplemented with material provided through virtual reality that can be obtained from other sources such as articles, papers or journals from the internet. Students get additional teaching materials and subject matter optimally without limited lesson hours according to the school schedule.Media Virtual reality in this research is an application designed for certain subjects so that in practice it can attract students' interest and enthusiasm for learning. In its development, virtual reality is made more interactive by using the Unity 3D application and VR Box tool, where virtual reality-based learning media will be equipped with 3D animations, images, videos and sounds.As stated above, so far, teachers only use power point media so that student learning activities are not maximal, which results in low scores, even many who do not reach MCC. Other causes, including limited learning hours. In Object Oriented Programming students face to face with the teacher only once a week with an allocation of $4 \times 45$ minutes, so the material delivered is not optimal and students still lack understanding of the subjects of Object Oriented Programming.In connection with that, Virtual Mediabased learning media was chosen as a support for the teaching and learning process in the subjects of Object Oriented Programming in class XI RPL SMK Negeri

Based on the results of preliminary observations through interviews with teachers, students consider the subjects of Object Oriented Programming to be a difficult subject, and it is evident that student learning outcomes are still below the MCC (Minimum Completion Criteria) with a percentage value of $60 \%$. It is the task for the teacher to find the right solution in solving the problem. According to Trianto (2011), how to teach good teachers is a key and prerequisite for students to learn well. One of the benchmarks that students have learned well, if students can learn what should be learned, so that learning outcomes reach MCC.

Based on the background as described above, the formulation of the problem in this study are: (1) how is the validity of virtual reality-based learning media on the subjects of object-oriented programming ?; (2) how the learning activities of Bangkalan 2 Vocational School students on object oriented programming subjects using virtual reality based learning media; (3) how is the response of Bangkalan 2 Vocational School students to object oriented programming subjects using virtual reality based learning media ?; (4) how the learning outcomes of the cognitive, affective, and psychomotor domains of Bangkalan State Vocational School students on object-oriented programming subjects with virtual realitybased learning media?

Based on the formulation of the above problem, the purpose of this study is to: (1) analyze the validity of virtual reality-based learning media on the subjects of object-oriented programming; (2) analyze the implementation of object-oriented programming learning using virtual reality-based learning media; (3) analyze the learning activities of Bangkalan Vocational High School 2 students on object oriented programming subjects using virtual reality based learning media; (4) analyze the response of students of SMK Negeri 2 Bangkalan to virtual reality-based learning media used in object-oriented programming subjects; (5) analyze the learning outcomes of SMK Negeri 2 Bangkalan students on object oriented programming subjects;

The expected benefits of the results of this study are: (1) can provide information for the development of science in the field of programming, especially learning object-oriented programming at SMK Negeri 2 Bangkalan; (2) the delivery of learning presented is more interesting and clarifies the understanding of material concepts so that it can attract students' attention in learning; (3) the resulting virtual reality based learning media can be used as a medium and source of learning independently for students, so that student learning outcomes increase. 


\section{LITERATURE REVIEW}

\subsection{Learning Media}

The word media is the plural form of the word medium. Medium is defined as an intermediary or introduction to communication from the sender to the recipient (Daryanto, 2012: 4). Whereas Media comes from Latin medius, which literally has a middle meaning or intermediary. In Arabic, the definition of media is as an intermediary or an introduction to a message from the sender to the recipient of the message Arsyad, [6]. While the notion of media in Latin is the plural form of the medium, and the boundaries regarding the notion of media are very broad. In this study, the notion of media is limited to learning media only, namely media that are used as tools and materials for learning activities Sadiman, [7].Ibrahim, Sihkabuden and Kustiawan [8] defines learning media as having a very broad scope, including human, material or study which builds a condition so that students acquire knowledge, skills and attitudes. Learning media is everything that can be used to channel messages (learning material), so it can stimulate attention, interests, thoughts, and goals of students' feelings in learning activities to achieve learning goals Daryanto, [5].

From the description, it can be concluded that the learning media is an intermediary that allows communication from the sender to the recipient that includes all the necessary resources, both hardware and software, including humans, and the material used to create a condition so that students can get an attitude, knowledge and skills in a particular field.

\subsection{Definition of Learning Outcomes}

Learning outcomes are abilities acquired by students after the learning process takes place so that changes in behavior occur in students, both in the form of knowledge, attitudes and skills so that student behavior becomes better than before. As stated by Hamalik [9], that learning outcomes are changes in subject behavior that includes cognitive, affective and psychomotor abilities that students have after receiving their learning experience. While according to Purwanto [10], learning outcomes are behavioral changes that occur after participating in the teaching and learning process in accordance with educational goals. Whereas according to Dimyati and Mudjiono [11], learning outcomes are the results achieved in the form of numbers or scores after being given a test of learning outcomes at the end of each lesson. Scores obtained by students become a reference to see students' mastery in receiving learning material. Furthermore Uno [12] argues that learning outcomes are statements that show what students might do as a result of learning from the learning activities they have done. So learning outcomes are learning experiences that students get in the form of certain abilities.

From some of the opinions mentioned above it can be concluded that learning outcomes are the results achieved by students in the form of numbers or scores obtained after going through the process of learning outcomes at the end of each lesson. The learning outcomes include learning outcomes in the cognitive, affective and psychomotor domains. Ranking of cognitive learning outcomes is: (1) remembering; (2) understand; (3) applying; (4) analyze; (5) evaluating; and (6) creating. While ranking affective domain learning outcomes, namely: (1) accept; (2) respond; (3) assess; (4) organizing; and (5) telling. While ranking psychomotor domains learning outcomes are: (1) imitating; (2) manipulation; (3) precision; (4) articulation; and (5) naturalization.

\subsection{Virtual Reality}

Virtual Reality (VR) was first named in 1989 written in several magazines and newspapers by Jaron Lanier who was the founder of the VPL research company. VR is a technology that uses computers and electronic technology to produce a realistic three-dimensional atmosphere so that users can feel through vision, hearing, touch and to form a virtual world Liu, [13]. According to Psotka [4], the notion of Virtual Reality is a technology that allows users to interact with an environment simulated by a computer (computer-simulated-environment), or an actual environment that is copied or truly an environment that is only in one's imagination. According to Zhang \& Zheng [14] VR technology is a kind of interface technology between humans and machines that can actually simulate people like being in a natural environment, including with vision, hearing, movement and other actions. VR is not only able to describe the environment in a real way, but VR also allows users to observe virtual environments and feel like they are in that place. 


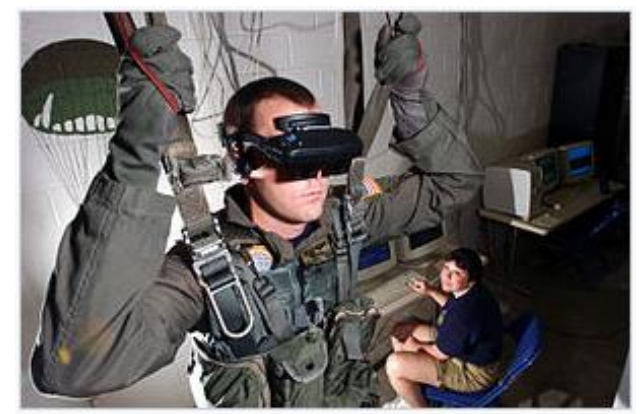

Figure 1.Simulation of Parachute Training in the Application of VR.

According to Widhiartha [15], that the basic concept of VR is trying to make a world inside a computer. Users use various tools to translate their movements so that they can be used to manipulate virtual objects. Although VR brings its users to explore the real world through simulation, but it cannot be denied that the display in VR remains a map and not an area in the real world. VR ignores the people around the user, ignores the user's seat, and various other real aspects. VR focuses its efforts on simulating the real world into computers rather than directly manipulating objects or the real world to solve a problem.

While according to Kurniadi [16], that Virtual Reality actually refers to a system that is very deep, although it has long been used to explain systems without virtual gloves and so on. Virtual Reality Modeling Language (VRML) is a programming language specifically created to create 3D objects. Objects made with VRML will have three dimensions, namely length, width, and depth, so that they can be viewed from every angle. VRML uses a very structured but simple language structure. VRML does not require programming logic to make it, and the commands are quite easy to memorize because they are formed from simple English which is similar to commands in HTML. While the structure of the VRML program that uses curly braces $(\{)$ and divides each part of the program into objects, is very similar to the programming language $\mathrm{C}$ or $\mathrm{C}++$. But it is not easy to create a VR with a high level of similarity in accordance with the real world. The problem is still around the limitations of technology for data processing, image resolution and communication bandwidth used. However, it turns out that these limitations can encourage the development of processors, images and data communication technologies that are increasingly sophisticated and economical.

From the description above it can be concluded that Virtual Reality (VR) is a technological tool that can interact between the environment and computer (computer-simulated-environment), so that a realistic three-dimensional atmosphere in the user can be felt through vision, hearing, touch and movement. Then VR simulates the real world into a computer and compares directly to objects or the real world in order to solve a problem.

\subsection{Research And Development Research (R \& D)}

Through Research and Development (R \& D) research there are many efforts that can be done by every citizen of education to improve the quality of education in Indonesia. Through research, the problems in education can be solved. In addition, through research can be developed and applied new things that are more innovative in education. There are several types of research that can be carried out, one of which is Research and Development (R \& D) research or research and development research.

At first this $\mathrm{R} \& \mathrm{D}$ research was applied in the industrial world, and was the spearhead of the industrial world to produce a new product, which this product really needed by the market. According to Borg and Gall [17], that almost $4 \%$ of business income is used to carry out this $\mathrm{R} \& \mathrm{D}$ research, even in certain fields such as the computer and pharmaceutical fields, R \& D fund allocation can be more than $4 \%$. Meanwhile, for the education and social fields, the costs for R \& D are still very small at less than $1 \%$ of the overall education costs. This is considered to be one of the main reasons why progress in the education sector has lagged behind when compared to other fields. This is consistent with what was revealed by Borg and Gall [17], that "unfortunately, R \& D still plays a minor role in education. Less than one percent of education expenditures are for this purpose. The progress in education has been logged for behind progress in other fields.

Borg and Gall [17], state that "educational research and development is a process used to develop and validate educational products", which means that education development research (R \& D) is a process used to develop and validate educational products. The results of this development research are 
not only for the development of an existing product, but also to find a knowledge or answer to practical problems. According to Sugiyono [18], research and development methods (R \& D) are research methods used to produce certain products, and test the effectiveness of a product. In order to be able to produce a particular product, it is used research that is needs analysis (with survey methods) and to test the effectiveness of the product used the experimental method. The process of testing products using experimental research is called applied research. Sugiyono (2013) states that the steps in R \& D research consist of the following 10 steps: (1) determining potential and problems; (2) collecting data; (3) designing products; (4) validating the design; (5) revise the design; (6) test products; (7) product revision (I); (8) test the use of products; (9) product revision (II); and (10) mass production of products.

\subsection{Validity}

Valid data is "not different" data between data reported by researchers with data that actually occurs in the object of research. Validity can measure the ability of a tool to measure what should be measured. According to Furchan [19], validity is a measure that shows the levels of validity or validity of an instrument. A measuring instrument can be said to be valid if the tool can measure what will be measured. So the validity of a measuring instrument depends on the extent of the accuracy of the measuring instrument in carrying out its functions Ratumanan, [20]. The concept of validity of a test consists of content validity, construct validity, and empirical validity Arikunto, [21].

\subsection{Implementation of Learning}

Implementation comes from the basic word like, the word implemented itself can be interpreted which means the object held and become a special sign of an area Depdiknas[22],. It can be said that the word implementation is more directed towards the process, not a result. Whereas according to Nasution Sugihartono [23], learning as an activity organizes or regulates the environment as well as possible and connects it with students so that learning processes occur in the environment. The environment in question is not only a learning room, but also includes teachers, teaching aids, libraries, laboratories, etc. that are relevant to student activities. Good learning is a learning process that aims to change behavior to be better than before and changes in behavior tend to be permanent.

According to Surachmad Sukintaka [24], so that the interaction of education can run smoothly, at least there must be components as follows: (1) the purpose to be achieved; (2) the existence of teaching material or material that becomes the content of the activity; (3) the existence of students who become subjects; (4) the existence of teachers who implement the curriculum; (5) the existence of facilities and infrastructure that support the implementation of the learning process; (6) the existence of methods to achieve goals; (7) the existence of a situation that allows for the learning process; and (8) the existence of research to determine the success of the learning process.From some of the opinions of the experts mentioned above, it can be concluded that the implementation of learning is a process that takes place or a reciprocal process between teacher and student and learning media to achieve the objectives in the curriculum. 


\subsection{Student Response}

According to Sarwono [25], response is every behavior, which is essentially a response or response to stimuli or stimuli. All forms of student behavior towards stimuli in the teaching and learning process become the attention of the teacher to be used as a reference in improving the teaching and learning process. Every human individual plays a role as a controller between the stimulus and response produced, so that it can determine the form of response to stimulus and individual factors Azwar [26],. Whereas according to Suprihatiningrum [27], that response is a result or impact, in the form of a physical reaction to stimulants as shown in Figure 2 below.

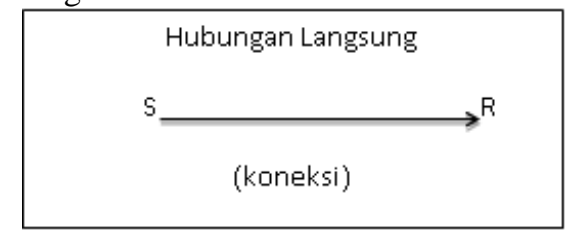

Figure 2.Scheme of Direct S (Stimulus) and R (Response) Relationship.

The occurrence of the learning process in the pattern of S-R relationships is indicated by the presence of elements of drive (stimulus), stimulus (stimulus), response, and reinforcement (reinforment). In learning behavior there is a close link between behavioral reactions and existing stimuli. According to Thorndike (Suprihatiningrum, 2013: 17), learning is the event of forming associations between events called stimulus ( $\mathrm{S}$ ) and response (R). Stimulus is a change from the external environment that becomes a sign to activate the organism to act or act, and the response is any behavior that is raised because of an incentive. The response can be found through a number of indicators.

Indicators of student responses to object oriented programming subjects are: (1) student responses to learning media; (2) student motivation in learning; (3) student work practices; (4) activeness of students in the learning process; (5) student opinions about the application of learning media; (6) students' seriousness towards learning media; (7) effectiveness of learning media; (8) students' understanding of the material; (9) increasing student knowledge; (10) students are more interactive; (11) students ask a lot; (12) students share knowledge with friends; (13) students can answer teacher questions; (14) students are more interested in using learning media; (15) student learning outcomes increase; (16) students discuss actively between fellow students and teachers.

\subsection{Learning Activities}

Activities can be defined as the activity of an activity Alwi [3]. Activities can also be interpreted as all activities that will be carried out by students both outside and inside the school. According to

Table 2.1Differences in learning activities for students who learn using VR media and students who learn with power point media, as well as their influence on cognitive learning outcomes.

\begin{tabular}{|c|c|c|}
\hline No. & $\begin{array}{l}\text { Activities of students who learn using } \\
\text { Virtual Reality learning media. }\end{array}$ & $\begin{array}{l}\text { Activities of students who learn to use } \\
\text { Power Point learning media. }\end{array}$ \\
\hline 1. & $\begin{array}{l}\text { Students can apply material that } \\
\text { presents text, images, animations, and } \\
\text { videos graphically / 3-D visualization. }\end{array}$ & $\begin{array}{l}\text { Students can apply material that presents } \\
\text { text, images, audio and video. }\end{array}$ \\
\hline 2. & $\begin{array}{l}\text { Analyze material that will enable users } \\
\text { to feel the sensations of the real world } \\
\text { in cyberspace. }\end{array}$ & $\begin{array}{l}\text { Cannot analyze material that can make } \\
\text { users feel real world sensations in } \\
\text { cyberspace like using VR. }\end{array}$ \\
\hline 3. & $\begin{array}{l}\text { Evaluate the material by selecting } \\
\text { multiple choices based on the detection } \\
\text { of user movements, such as head } \\
\text { motion and the direction of user's } \\
\text { eyeball movements. }\end{array}$ & $\begin{array}{l}\text { Unable to evaluate material by selecting } \\
\text { multiple choices based on the detection } \\
\text { of user movements, such as head motion } \\
\text { and eyeball direction movements. }\end{array}$ \\
\hline 4. & $\begin{array}{l}\text { Students can create applications } \\
\text { because of simulations. }\end{array}$ & $\begin{array}{l}\text { Students cannot create applications } \\
\text { because they are only slides. }\end{array}$ \\
\hline
\end{tabular}

Table 2.2 shows the differences in learning activities for students who learn by using VR media and students who learn with power point media, and the effect on affective learning outcomes. 
Table 2.2Differences in learning activities for students who study using VR media and students who learn with power point media, and their influence on the learning outcomes of the affective domain.

\begin{tabular}{|c|c|c|}
\hline No. & $\begin{array}{c}\text { Activities of students who learn using Virtual } \\
\text { Reality learning media. }\end{array}$ & $\begin{array}{l}\text { Activities of students who learn to use Power } \\
\text { Point learning media. }\end{array}$ \\
\hline 1. & $\begin{array}{l}\text { Students can follow the learning process in the } \\
\text { form of text, images, animation, and video } \\
\text { graphically / 3-D visualization. }\end{array}$ & $\begin{array}{l}\text { Students can follow the learning process in the } \\
\text { form of text, images, audio and video. }\end{array}$ \\
\hline 2. & $\begin{array}{l}\text { Comply with regulations when using a VR Box } \\
\text { to provide an experience that makes users feel } \\
\text { the sensation of the real world in cyberspace. }\end{array}$ & $\begin{array}{l}\text { Unable to comply with regulations when using } \\
\text { Power Point because students pay less } \\
\text { attention to teacher explanations. }\end{array}$ \\
\hline 3. & $\begin{array}{l}\text { Prove it by trying to find information about the } \\
\text { use of the Virtual Reality Box, which is the } \\
\text { ability to detect user movements, such as head } \\
\text { movements and eyeball direction movements. }\end{array}$ & $\begin{array}{l}\text { Siswa tidak dapat mencari informasi pada } \\
\text { penggunaan Power Point karena Power Point } \\
\text { sudah lumrah digunakan. }\end{array}$ \\
\hline 4. & $\begin{array}{l}\text { Students can complete the practicum on time } \\
\text { with discipline because Virtual Reality can } \\
\text { simulate learning in cyberspace so the teacher } \\
\text { does not need to explain. }\end{array}$ & $\begin{array}{l}\text { Practicum is difficult to solve because students } \\
\text { need teacher explanations that are too long } \\
\text { with Power Point media. }\end{array}$ \\
\hline
\end{tabular}

Table 2.3 shows the differences in learning activities for students who learn using VR media and students who learn with power point media, as well as their influence on psychomotor domain learning outcomes.

Table 2.3.Differences in learning activities for students who learn using VR media and students who learn with power point media, as well as their influence on psychomotor domain learning outcomes.

\begin{tabular}{lll}
\hline No. & $\begin{array}{l}\text { Activities of students who learn using Virtual } \\
\text { Reality learning media. }\end{array}$ & $\begin{array}{l}\text { Activities of students who learn to use Power } \\
\text { Point learning media. }\end{array}$ \\
\hline 1. & $\begin{array}{l}\text { Students quickly make applications on the } \\
\text { netbeans software because of the display in the } \\
\text { form of text, images, animation, and video } \\
\text { graphically / 3-D visualization. }\end{array}$ & $\begin{array}{l}\text { Less skilled students make applications on } \\
\text { netbeans software because of the appearance } \\
\text { of text, images, audio and video. }\end{array}$ \\
\hline Making the application easily because of the \\
$\begin{array}{l}\text { experience that allows users to feel the sensation } \\
\text { of the real world in cyberspace. }\end{array}$
\end{tabular}

Indicators of learning activities in object-oriented programming subjects are: (1) students' readiness to accept object-oriented programming subjects; (2) student enthusiasm in accepting object oriented programming learning; (3) seriousness in learning; (4) trust in one's abilities; (5) opportunity to express opinions; (6) respect for opinions; (7) smooth communication; (8) accuracy of questions; (9) accuracy of answers; (10) enthusiastic in responding to questions; (11) active in reviving the atmosphere; (12) responsive to giving opinions; (13) effective in learning; (14) raise new questions; (15) care for friends; (16) submit opinions; (17) completion of assignments on time; (18) explanation of assignments; and (19) relevant to the work done. 


\section{RESEARCH METHODS}

This research includes development research (R \& D). Products developed in the form of virtual reality based learning media, through eight stages of the overall stages in the $R$ \& $D$ process Sugiyono[18]. Broadly speaking, the research procedures as shown in Table 3 below.

Tabel 3. Prosedur Penelitian R \& D

\begin{tabular}{ll}
\multicolumn{1}{c}{$\begin{array}{c}\text { Tahapan R\&D } \\
\text { (Sugiyono: 2013) }\end{array}$} & \multicolumn{1}{c}{ Kegiatan } \\
\hline 1. Potensi dan Masalah & Melakukan observasi dan wawancara. \\
\hline 2. Pengumpulan Informasi & Merancang desain media pembelajaran. \\
\hline 3. Desai Produk & Validasi media ke validator. \\
\hline 4. Validasi Desain & Perbaiki kekurangan dari media. \\
\hline 5. Perbaikan Desain & $\begin{array}{l}\text { Uji coba ke kelas experimen dan kelas } \\
\text { kontrol. }\end{array}$ \\
\hline 6. Uji coba produk. & \begin{tabular}{l} 
Tidak terjadi kekurangan dalam produk. \\
\hline 7. Revisi Produk.
\end{tabular} \\
\hline 8. Uji coba pemakaian. & $\begin{array}{l}\text { Media pembelajaran dilakukan dalam } \\
\text { mata pelajaran Pemrograman Berorientasi } \\
\text { Objek. }\end{array}$ \\
\hline
\end{tabular}

Sugiyono[18]

Empirical trials of learning media developed, carried out through Pretest-Posttest Control Group Design as shown in Figure 1 below.

\begin{tabular}{lccc}
\hline Kelompok & Pretest & Perlakuan & Postes \\
\hline Eksperimen & $\mathrm{O}_{1}$ & $\mathrm{X}_{1}$ & $\mathrm{O}_{2}$ \\
\hline Kontrol & $\mathrm{O}_{3}$ & $\mathrm{X}_{2}$ & $\mathrm{O}_{4}$ \\
\hline
\end{tabular}

Figure 3. Research Design for Empirical VR Media Trial

The place of the study was conducted in SMK Negeri 2 Bangkalan, with the implementation time adjusted to the schedule of the object-oriented programming learning activities, namely March-April 2018. The research subjects for the experimental class were SMK Negeri 2 Bangkalan class XI (RPL) -1 with the number of students as many as 30 people, and the control class subjects were class XI (RPL) -2 with a total of 30 students. The instruments used in this study were observation sheets of student learning activities, learning outcomes tests, student response questionnaire sheets, and validation sheets. The techniques and instruments for data collection are shown in Table 4 below.

Table 4. Techniques and Data Collection Instruments

\begin{tabular}{lll}
\hline $\begin{array}{c}\text { Teknik } \\
\text { Pengumpulan } \\
\text { Data }\end{array}$ & \multicolumn{1}{c}{ Instrumen } & \multicolumn{1}{c}{ Keterangan } \\
\hline $\begin{array}{l}\text { Observasi dan } \\
\text { wawancara }\end{array}$ & $\begin{array}{l}\text { Lembar observasi media } \\
\text { pembelajaran dan lembar } \\
\text { wawancara }\end{array}$ & $\begin{array}{l}\text { Pengumpulan data kondisi media } \\
\text { pembelajaran dan kemampuan siswa } \\
\text { yang ada di sekolah SMKN 2 } \\
\text { Bangkalan. }\end{array}$ \\
\hline Validasi & Lembar validasi media & $\begin{array}{l}\text { Digunakan untuk mendeksripsikan } \\
\text { kualitas media pembelajaran yang } \\
\text { dikembangkan. }\end{array}$ \\
\hline pembelajaran & $\begin{array}{l}\text { Digunakan untuk mendeskripsikan } \\
\text { aktivitas belajar siswa yang diajar }\end{array}$ \\
\hline
\end{tabular}




\begin{tabular}{|c|c|c|}
\hline $\begin{array}{c}\text { Teknik } \\
\text { Pengumpulan } \\
\text { Data }\end{array}$ & Instrumen & Keterangan \\
\hline & & $\begin{array}{l}\text { dengan menggunakan media } \\
\text { pembelajaran berbasis virtual reality. }\end{array}$ \\
\hline Tes & Lembar tes hasil belajar siswa & $\begin{array}{l}\text { Digunakan untuk menganalisis hasil } \\
\text { belajar siswa sebelum dan sesudah } \\
\text { diajar menggunakan media } \\
\text { pembelajaran berbasis virtual reality. }\end{array}$ \\
\hline Angket & Lembar angket respon siswa & $\begin{array}{l}\text { Digunakan untuk mendeskripsikan } \\
\text { respon siswa yang diajar dengan } \\
\text { menggunakan media pembelajaran } \\
\text { berbasis virtual reality. }\end{array}$ \\
\hline
\end{tabular}

\section{RESULTS AND DISCUSSION}

In the initial stage a survey was conducted to find out the existence of a problem, through the method of observation and interview with the Head of Department, Teachers and Students majoring in Software Engineering at SMK Negeri 2 Bangkalan. The results of observations and interviews indicate that the learning media used in SMK Negeri 2 Bangkalan, are conventional learning media in the form of PPT, while VR-based learning media have not been used. Learning media have not been accompanied by LKS, so students have difficulty achieving the learning goals set by the teacher. In order to improve the learning outcomes of students majoring in Software Engineering, virtual reality-based learning media are needed.

The second stage is the stage of designing virtual reality-based learning media design, which is tailored to the learning objectives in the 2013 curriculum. Indicators that need to be considered in designing instructional media designs are: (1) the suitability of learning media with students' abilities; (2) learning media in accordance with curriculum objectives; and (3) ease of operation of learning media.

\subsection{Results of Learning Media Validation}

The third stage is the stage of validation and revision of virtual reality based learning media. Based on the results of the validation, the learning media developed in good / valid categories with the average score details are as follows: (1) the average score of the validator 1 is 3.82 ; (2) the average score of validator 2 is 3.14; and (3) the average score of the validator 3 is 3.52 . Thus it can be concluded that the virtual reality learning media is feasible to use with little revision. Suggestions from expert validators are design improvements and improvements to material content. Another suggestion from the validators is adjusting the learning indicators with virtual reality based learning media. The results of the validation of virtual reality-based learning media developed appear like Figure 4 below.

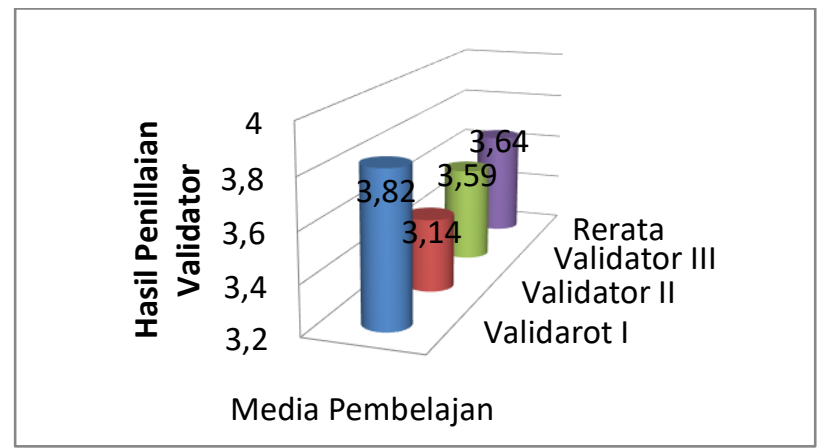

Figure 4. Bar Diagram of Learning Media Validation Results

\subsection{Product Test Results}

The fourth stage is the product testing phase and product revision. At this stage, virtual reality based learning media (VR) are tested on students in the teaching and learning process in the classroom through "Pretest-Posttest Control Group Design". Student learning outcomes before and after participating in learning using VR media as shown in Table 5 below. 
Table 5. Learning Outcomes of the Cognitive RealmStudents of Bangkalan State Vocational High School Class XI RPL-1 and Class RPL-2

\begin{tabular}{ll|lll}
\hline \multirow{2}{*}{$\begin{array}{l}\text { Kiswa } \\
\text { Ke }\end{array}$} & \multicolumn{2}{l}{ Kelas Kontrol } & \multicolumn{2}{l}{ Kelas Eksperimen } \\
\cline { 2 - 5 } & pre-test & post-test & pre-test & post-test \\
\hline 1 & 48 & 65 & 65 & 88 \\
\hline 2 & 45 & 63 & 70 & 95 \\
\hline 3 & 40 & 55 & 65 & 85 \\
\hline 4 & 48 & 65 & 45 & 78 \\
\hline 5 & 33 & 48 & 55 & 93 \\
\hline 6 & 30 & 55 & 50 & 90 \\
\hline 7 & 48 & 65 & 48 & 95 \\
\hline 8 & 40 & 55 & 43 & 80 \\
\hline 9 & 48 & 65 & 58 & 83 \\
\hline 10 & 60 & 78 & 63 & 88 \\
\hline 11 & 45 & 63 & 65 & 88 \\
\hline 12 & 48 & 63 & 58 & 88 \\
\hline 13 & 48 & 63 & 43 & 78 \\
\hline 14 & 48 & 63 & 43 & 85 \\
\hline 15 & 35 & 50 & 45 & 78 \\
\hline 16 & 35 & 50 & 53 & 80 \\
\hline 17 & 43 & 58 & 43 & 93 \\
\hline 18 & 58 & 78 & 50 & 95 \\
\hline 19 & 45 & 60 & 40 & 78 \\
\hline 20 & 58 & 78 & 30 & 85 \\
\hline 21 & 45 & 60 & 45 & 90 \\
\hline 22 & 45 & 60 & 38 & 78 \\
\hline 23 & 45 & 60 & 40 & 75 \\
\hline 24 & 43 & 58 & 40 & 75 \\
\hline 25 & 38 & 53 & 43 & 75 \\
\hline 26 & 45 & 60 & 43 & 88 \\
\hline 27 & 35 & 50 & 50 & 88 \\
\hline 28 & 25 & 45 & 40 & 83 \\
\hline 29 & 40 & 55 & 48 & 78 \\
\hline 30 & 35 & 50 & 38 & 75 \\
\hline Rata- & 43 & 60 & 48 & 84 \\
\hline Rata & & & & \\
\hline & & 53 \\
\hline
\end{tabular}

From Table 5 above, it can be seen that the average posttest score of the control class is 60 ; while the average score for the experimental class is 84 . In the control class, there are 3 students who graduate, while in the experimental class there are 30 students who graduate with MCC of 75.Furthermore, through the assessment of affective domain learning outcomes, the posttest mean score in the control class was 58; and the posttest mean score in the experimental class was 81 . There were 3 students who graduated in the control class, while for the experimental class there were 3 students who did not graduate, and there were as many as 27 students who passed the MCC at 75. The following were affective domain learning outcomes presented below. 
Table 6. Learning Outcomes of Affective AreasStudents of Bangkalan State Vocational High School Class XI RPL-1 and Class RPL-2

\begin{tabular}{|c|c|c|}
\hline \multirow{2}{*}{$\begin{array}{c}\text { Siswa } \\
\text { Ke }\end{array}$} & Kelas Kontrol & Kelas Eksperimen \\
\hline & Post-Test & Post-Test \\
\hline 1 & 50 & 88 \\
\hline 2 & 63 & 78 \\
\hline 3 & 55 & 85 \\
\hline 4 & 65 & 78 \\
\hline 5 & 48 & 93 \\
\hline 6 & 55 & 90 \\
\hline 7 & 65 & 80 \\
\hline 8 & 55 & 95 \\
\hline 9 & 50 & 83 \\
\hline 10 & 78 & 88 \\
\hline 11 & 63 & 75 \\
\hline 12 & 63 & 88 \\
\hline 13 & 63 & 78 \\
\hline 14 & 63 & 85 \\
\hline 15 & 50 & 78 \\
\hline 16 & 50 & 80 \\
\hline 17 & 58 & 70 \\
\hline 18 & 78 & 95 \\
\hline 19 & 60 & 78 \\
\hline 20 & 78 & 85 \\
\hline 21 & 60 & 90 \\
\hline 22 & 50 & 78 \\
\hline 23 & 60 & 75 \\
\hline 24 & 58 & 70 \\
\hline 25 & 53 & 75 \\
\hline 26 & 60 & 75 \\
\hline 27 & 50 & 70 \\
\hline 28 & 45 & 83 \\
\hline 29 & 55 & 78 \\
\hline 30 & 50 & 75 \\
\hline $\begin{array}{l}\text { Rata- } \\
\text { Rata }\end{array}$ & 58 & 81 \\
\hline
\end{tabular}

Then, through the assessment of psychomotor domains of learning, posttest mean scores on the control class were 60; while the posttest mean score in the experimental class was 83 . There were 3 students who graduated in the control class, while for the experimental class there were 2 students who did not graduate, and as many as 28 students who graduated with MCC were 75 . Psychomotor domains were as shown in Table 7 below: 
Table 7. Learning Outcomes of the Psychomotor DomainStudents of Bangkalan State Vocational High School Class XI RPL-1 and Class RPL-2

\begin{tabular}{|c|c|c|}
\hline \multirow{2}{*}{ Siswa Ke } & Kelas Kontrol & Kelas Eksperimen \\
\hline & Post-Test & Post-Test \\
\hline 1 & 50 & 85 \\
\hline 2 & 63 & 78 \\
\hline 3 & 55 & 88 \\
\hline 4 & 65 & 70 \\
\hline 5 & 48 & 88 \\
\hline 6 & 55 & 70 \\
\hline 7 & 65 & 80 \\
\hline 8 & 78 & 95 \\
\hline 9 & 65 & 83 \\
\hline 10 & 55 & 88 \\
\hline 11 & 63 & 93 \\
\hline 12 & 55 & 88 \\
\hline 13 & 60 & 78 \\
\hline 14 & 63 & 85 \\
\hline 15 & 65 & 78 \\
\hline 16 & 50 & 80 \\
\hline 17 & 63 & 78 \\
\hline 18 & 78 & 95 \\
\hline 19 & 60 & 78 \\
\hline 20 & 78 & 85 \\
\hline 21 & 60 & 90 \\
\hline 22 & 58 & 88 \\
\hline 23 & 60 & 75 \\
\hline 24 & 53 & 90 \\
\hline 25 & 58 & 75 \\
\hline 26 & 45 & 88 \\
\hline 27 & 50 & 78 \\
\hline 28 & 60 & 83 \\
\hline 29 & 63 & 78 \\
\hline 30 & 50 & 75 \\
\hline Rata-Rata & 60 & 83 \\
\hline
\end{tabular}

\subsection{Results of Implementation of Learning Media}

The implementation of virtual reality based learning media on object oriented programming subjects, using the direct learning model (MPL) and the results of the assessment of learning implementation by three teachers in Bangkalan 2 SMKN in class XI RPL 1 as shown in Figure 5 below. 


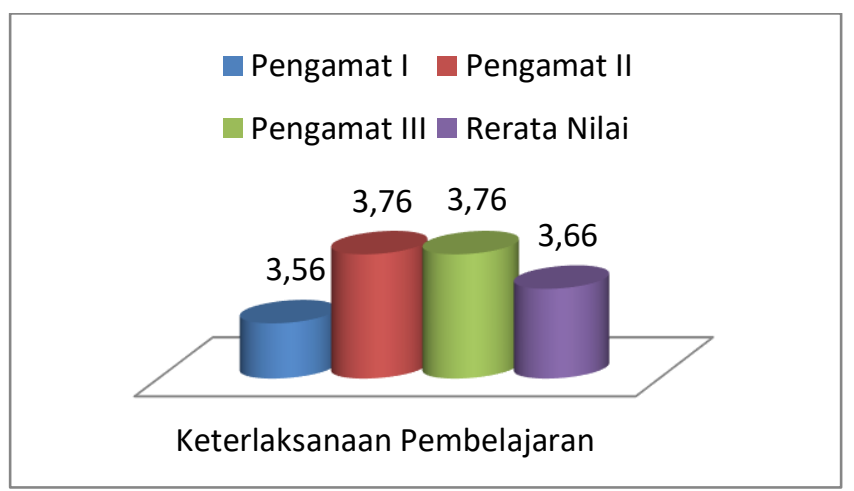

Figure 5. Rod Diagram of the Results of the Implementation of Learning Media.

Based on Figure 5 it can be concluded that the implementation of virtual reality (VR) based learning media with object oriented programming subjects, obtained an average score of 3.66 with the category "done well".

\subsection{Student Response to Media VR}

Based on the questionnaire obtained responses of class XI RPL-1 students to VR media, with details as many as 28 students stated strongly agree that VR media is used in learning, and the remaining 2 students agreed that VR media was used in the learning process on object oriented programming subjects with basic concept material.

\subsection{Student Learning Activities}

Based on observations through the observation sheet on the learning activities of class XI RPL-1 students, it was concluded that as many as 30 students were active in participating in the learning process on object-oriented programming subjects through VR media assistance. 11 students included the active category, and the remaining 1 student included the less active category.

\subsection{Data Analysis Requirements Test}

The first condition test is the normality test. The results of the normality test on cognitive domain learning data as shown in Table 8. For the experimental class obtained the value of pretest significance of $0.35>0.05$ and the posttest significance value was $0.44>0.05$ while for the control class the significance value of the pretest was obtained is $0.09>0.05$ and the posttest significance value is $0.39>0.05$. Thus it can be concluded that cognitive learning outcomes data are normally distributed.

Table 8. Normality Test Results for Learning Data Data Cognitive domain of Bangkalan Vocational High School Students Class XI RPL-1 and Class RPL-2

Tests of Normality
\begin{tabular}{|l|l|r|r|r|}
\hline & \multicolumn{4}{|l|}{$\begin{array}{l}\text { Kolmogorov- } \\
\text { Smirnov }\end{array}$} \\
\cline { 3 - 6 } & Kelas & Statistic & df & Sig. \\
\hline Hasil Belajar & Pretes Eksperimen &, 165 & 30 &, 035 \\
Ranah Kognitif & Posttest Eksperimen &, 162 & 30 &, 044 \\
& Pretes Kontrol &, 187 & 30 &, 009 \\
& Posttest Kontrol &, 164 & 30 &, 039 \\
\hline
\end{tabular}

Furthermore, the results of the normality test for affective learning outcomes data as shown in Table 9. It can be seen that for the experimental class, the posttest significance value is $0.18>0.05$ while 
the posttest significance value is $0.198>0.05$ for the control class. Thus it can be concluded that the affective learning outcomes data are normally distributed.

Table 9. Normality Test Results for Learning Data Data Affective Territory of Bangkalan Vocational School Class XI RPL-1 and Class RPL-2

Tests of Normality

\begin{tabular}{|l|l|r|r|r|}
\hline & & \multicolumn{3}{|c|}{$\begin{array}{c}\text { Kolmogorov- } \\
\text { Smirnov }\end{array}$} \\
\cline { 3 - 5 } & Kelas & Statistic & df & Sig. \\
\hline Hasil Belajar & Post Tes Eksperimen &, 176 & 30 &, 018 \\
Ranah Afektif & Post Tes Kontrol &, 131 & 30 &, 198 \\
\hline
\end{tabular}

The results of the test for normality of psychomotor domain learning outcomes data as shown in Table 10. It can be seen that for the experimental class the posttest significance value is $0.18>0.05$ while for the control class the posttest significance value is $0.12>0.05$. Thus it can be concluded that psychomotor domain learning outcomes data are normally distributed.

Table 10. Normality Test Results for Learning Data Data Psychomotor domains of Bangkalan Vocational High School Students Class XI RPL-1 and Class RPL-2

Tests of Normality

\begin{tabular}{|l|l|r|r|r|}
\hline & & \multicolumn{3}{|l|}{$\begin{array}{l}\text { Kolmogorov- } \\
\text { Smirnov }\end{array}$} \\
\cline { 3 - 5 } & \multirow{2}{*}{ Kelas } & Statistic & df & Sig. \\
\hline $\begin{array}{l}\text { Hasil Belajar } \\
\text { Ranah }\end{array}$ & Post Tes Eksperimen \\
Psikomotor & Post Tes Kontrol &, 176 & 30 &, 018 \\
\end{tabular}

The second condition test is the homogeneity test. The homogeneity test results on cognitive domain learning outcomes data as shown in Table 11. It can be seen that the significance value of the posttest results is $0.629>0.05$. Thus it can be concluded that cognitive learning outcomes data from both groups namely the experimental class and the control class have the same or homogeneous population variants.

Table 11. Homogeneity Test Results on Learning Data Data Cognitive domain of Bangkalan Vocational High School Students Class XI RPL-1 and Class RPL-2

\begin{tabular}{|c|c|c|c|}
\hline $\begin{array}{l}\text { Levene } \\
\text { Statistic }\end{array}$ & df1 & df 2 & Sig. \\
\hline 236 & 1 & 58 & ,629 \\
\hline
\end{tabular}

The homogeneity test results on affective domain learning outcomes data as shown in Table 12. It can be seen that the significance value of the posttest results is $0.548>0.05$. Thus it can be concluded that affective domain learning data from the two groups namely the experimental class and the control class have the same or homogeneous population variants.

Table 12. Homogeneity Test Results on Learning Data Data Affective Areas of Bangkalan Vocational High School Students Class XI RPL-1 and Class RPL-2

\begin{tabular}{|l|l|l|l|}
\hline Levene Statistic & df1 & df2 & Sig. \\
\hline
\end{tabular}




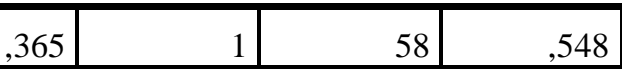

The homogeneity test results on psychomotor domain learning outcomes data as shown in Table 13. It can be seen that the significance value of the posttest results is $0.719>0.05$. Thus it can be concluded that psychomotor domain learning outcomes data from both groups namely the experimental class and the control class have the same or homogeneous population variants.

Table 13. Homogeneity Test Results on Learning Outcomes Psychomotor domains of Bangkalan Vocational High School Students Class XI RPL-1 and Class RPL-2

\begin{tabular}{|c|c|c|c|}
\hline Levene Statistic & df1 & df 2 & Sig. \\
\hline, 130 & 1 & 58 & ,719 \\
\hline
\end{tabular}

\subsection{Hypothesis Test}

Based on the prerequisite test (assumption) on the cognitive, affective and psychomotor domains of learning outcomes data (normally distributed and having homogeneous variants), the next step is to analyze the data using one way anava test statistical techniques. The results of hypothesis testing on cognitive learning outcomes are presented in Table 14 below.

Table 14. Hypothesis Test Results on Learning Outcomes in the Cognitive Realm.

\begin{tabular}{|l|r|l|l|l|l|}
\hline & $\begin{array}{l}\text { Sum of } \\
\text { Squares }\end{array}$ & df & $\begin{array}{l}\text { Mean } \\
\text { Square }\end{array}$ & F & Sig. \\
\hline Between Groups & $\begin{array}{r}9052,81 \\
7\end{array}$ & 1 & 9052,817 & 158,71 & \\
Within Groups & 3308,16 & 7 &, 000 \\
7 & 58 & 57,037 & & \\
Total & 12360,9 & 59 & & & \\
83 & 59 & & & \\
\hline
\end{tabular}

Based on Table 14 above, it can be seen that cognitive learning outcomes have a calculated $\mathrm{F}$ value of 158.717 and a significance of $0.000<0.05$ ) which means $\mathrm{H}_{0}$ and $\mathrm{H}_{1}$ are accepted. Thus it can be concluded that cognitive learning outcomes for students who learn using virtual reality-based learning media are significantly higher than students who learn using power point. Furthermore, the results of hypothesis testing of affective learning outcomes are presented in Table 15 below.

Table 15. Hypothesis Test Results on Learning Outcomes of Affective Areas.

\begin{tabular}{|l|l|r|l|l|l|}
\hline & $\begin{array}{l}\text { Sum of } \\
\text { Squares }\end{array}$ & df & $\begin{array}{l}\text { Mean } \\
\text { Square }\end{array}$ & F & Sig. \\
\hline Between Groups & & & & 12 & \\
& 7889,067 & 1 & 7889,067 & 3,0 &, 000 \\
& 3719,267 & 58 & 64,125 & & \\
Within Groups & 11608,333 & 59 & & & \\
Total & & & & 26 & \\
\hline
\end{tabular}

Based on Table 15 above it can be seen that cognitive learning outcomes have a calculated $F$ value of 123.026 and a significance of $0.000<0.05$ ) which means $\mathrm{H}_{0}$ and $\mathrm{H}_{1}$ are accepted. Thus it can be concluded that affective domain learning outcomes for students who study using virtual reality-based 
learning media are significantly higher than students who learn using power point. Furthermore, the results of hypothesis testing on psychomotor domain learning outcomes as presented in Table 16 below.

Table 16. Hypothesis Test Results on Learning Outcomes Psychomotor domains

\begin{tabular}{|l|l|r|l|l|l|}
\hline & $\begin{array}{l}\text { Sum of } \\
\text { Squares }\end{array}$ & df & $\begin{array}{l}\text { Mean } \\
\text { Square }\end{array}$ & F & Sig. \\
\hline Between Groups & 7981,067 & 1 & 7981,067 & 135,762 &, 000 \\
Within Groups & 3409,667 & 58 & 58,787 & & \\
Total & 11390,733 & 59 & & & \\
\hline
\end{tabular}

Based on Table 16 above it can be seen that cognitive learning outcomes have a calculated $F$ value of 135.762 and a significance of $0.000<0.05$ ) which means $\mathrm{H}_{0}$ and $\mathrm{H}_{1}$ are accepted. Thus it can be concluded that psychomotor domain learning outcomes for students learning using virtual reality-based learning media are significantly higher than students who learn using power point.

\section{DISCUSSION}

\subsection{Effect of virtual reality (VR) based learning media on learning activities}

Based on observations through the observation sheet on the learning activities of class XI RPL-1 students, it was concluded that as many as 30 students were active in participating in the learning process on object-oriented programming subjects through VR media assistance. 11 students included the active category, and the remaining 1 student included the less active category. Through this research, the following findings were obtained: (1) by using VR-based learning media students were able to make applications on netbeans software quickly because of the appearance of 3-D animation; and (2) students are able to make projects in accordance with the material contained in the subjects of object-oriented programming. The results of this study are in line with the results of research by Zhang and Liu (2016) who concluded that optimizing the teaching process, training students with innovative awareness and abilities. Other studies are in line, namely the research of Chuanwei and Yanfei (2015) with the title "Design and Research of Distance Education Based on Virtual Reality Platforms", which concludes that students can play a role in virtual learning environments, which greatly enhance students' independent learning abilities.Other studies are in line, namely the research of Ji and Zhang (2016) with the title "Integration and Application of Animation Production Simplification in a VR Virtual Reality Teaching System", which concludes that interactive classroom activities between students and teachers greatly contribute to the effectiveness of teaching "production 3D animation ". This research is also in line with the theories that state that learning media is an intermediary for communication from the sender to the recipient that includes all necessary resources in the form of hardware and software, including human (human), material or studies that are used to build a condition that help students to gain knowledge, skills and attitudes. VR-based learning media is a technological tool that can interact between environments by computers (computer-simulated-environment), so that a realistic three-dimensional atmosphere in the user can feel through vision, hearing, touch and movement. Then simulate the real world into a computer and compare it directly to objects or the real world with the aim of solving a problem. The findings of student learning activities can be caused by: (1) virtual reality based learning media capable of making applications on netbeans software quickly because of the appearance of 3-D animation; (2) XI RPL 1 grade students are able to make application easily because of the experience that allows users to feel the sensation of the real world in cyberspace; and (3) students are able to make a project consisting of objects, abstraction, inheritance, encapsulation, and polymorphism with netbeans software.

\subsection{Learning outcomes in the cognitive, affective, and psychomotor domains on object oriented programming subjects.}

1. Cognitive learning outcomes for students who learn using virtual reality-based learning media, are significantly higher than students who learn using power point 
Indicators of cognitive learning outcomes in this study, namely: (1) applying objects, methods, properties, abstractions, inheritance, encapsulation, polymorphism in java programming; (2) analyzing objects, methods, properties, abstractions, inheritance, encapsulation, polymorphism in the java programming language; (3) evaluating objects, methods, properties, abstractions, inheritance, encapsulation, polymorphism in the java programming language; and (4) creating objects, methods, properties, abstractions, inheritance, encapsulation, polymorphism in java programming. This can be seen from the significance of the One Way Anava test for cognitive domain learning outcomes of $0,000<0,05$. Through this research, it was found that students who learned using VR learning media were able to: (1) apply object, method, property, abstraction, inheritance, encapsulation, and polymorphism in java programming; (2) analyze object, method, property, abstraction, inheritance, encapsulation, and polymorphism in the java programming language; (3) evaluate object

This research is also in line with theories that state that virtual reality-based learning media can improve student learning outcomes that include learning outcomes in the cognitive, affective, and psychomotor domains. Virtual reality based learning media that can be accessed using a smartphone cellphone, so that it can improve student learning outcomes. Especially on the subjects of object oriented programming. In addition learning through virtual reality based learning media makes it easier for teachers to explain basic concept material.The findings of the cognitive learning outcomes of the students can be caused by: (1) in general Bangkalan 2 Vocational High School students, especially class XI RPL, have less interest in the basic concept material in object-oriented programming subjects that are cognitive in nature, cognitive learning using media virtual reality based learning that is guided and observed by the teacher during the learning process, can slowly attract the attention of students to study material related to cognitive learning outcomes; and (2) students are permitted to use smartphones during the learning process on object-oriented programming subjects so students can access learning media based on virtual reality and are trained to study material independently. The material learning process related to cognitive learning outcomes conducted independently by students can optimize students' cognitive abilities.

\section{Affective domain learning outcomes for students who study using virtual reality-based learning media, significantly higher than students who learn using power point}

Indicators of affective learning outcomes in the Object-Oriented Programming subjects in this study are as follows: (1) shows the attitude of prayer before and after the learning process of objectoriented programming; (2) giving greetings at the beginning and end of the learning process of objectoriented programming; (3) comply with applicable regulations while in the practicum room; (4) follow the learning process when the teacher is explaining object oriented programming; (5) do proof by trying as much as possible to find information about the functions of object-oriented programming; (6) establish good relationships with friends in practicing object-oriented programming; (7) showed an honest attitude by not cheating at the time of the pretest and posttest in object-oriented programming material; (8) report the results of object-oriented programming practicum based on data or information honestly; (9) completing practicum on time with discipline; (10) demonstrate the disciplinary behavior of practicing clothing in accordance with the RPL expertise study program when practicing object-oriented programming; (11) organize an atmosphere of competition in a healthy manner by working hard and carefully in using practical tools with full responsibility; (12) can treat practicum equipment in accordance with functions and pay attention to K3; (13) show active participation in cleaning the workplace and practicum tools after practicing object-oriented programming carefully; (14) can return complete tools and materials with full responsibility; (15) collaborating during the learning process of object-oriented programming; (16) show an attitude of not despair and always try to succeed, when the results of object-oriented programming practice fail; (17) classify the use of practicum tools with full responsibility and caution; (18) prove by trying and working hard to complete the practicum that must be collected on time with discipline; (19) solve problems when practicing object oriented programming; and (20) display the best when demonstrating the results of the practice of object oriented programming.

This can be seen from the significance level of One Way Anava test for affective domain learning outcomes of $0,000<0,05$. Through this research, it was found that students were able to: (1) demonstrate the attitude of prayer before and after the learning process of object-oriented programming; (2) giving greetings at the beginning and end of the learning process of object-oriented programming; (3) comply with applicable regulations while in the practicum room; (4) follow the learning process when the teacher 
is explaining object oriented programming; (5) prove by trying as much as possible to find information about the functions of object-oriented programming; (6) build good relations with friends in practicing object-oriented programming; (7) show honesty by not cheating on the implementation of the pretest and posttest

The results of this study on virtual reality-based learning media are in line with Bian's research results (2016) with the title "Application of Virtual Reality in Music Teaching Systems", which concluded that experimental results showed that using media virtual reality students enthusiasm in independent learning and learning efficiency has increased. Similarly, the results of research on virtual reality-based learning media are in line with research conducted by Ji and Zhang (2016) with the title "Integration and Application of Animation Production Simplification in a VR Virtual Reality Teaching System", which concludes that classroom activities can be interactive between students and teachers greatly contribute to increasing the effectiveness of teaching "3D animation production". This research is also in line with the results of research conducted by Ray and Deb (2016) with the title "Smartphone Based Virtual Reality Systems in Classroom Teaching and Learning Outcomes", which concluded that the results in using media based on virtual reality learning can improve teaching and learning processes and student interests.

This research is also in line with the theories which state that learning media based on virtual reality are based on learning objectives which include cognitive, affective, and psychomotor domains. Virtual reality based learning media that can be accessed using a smartphone cellphone, so that it can improve student learning outcomes. Especially on the subjects of object oriented programming. In addition learning through virtual reality based learning media makes it easier for teachers to explain basic concept material.

The affective learning outcomes of students can be caused by the eyes of object oriented programming learning using virtual reality-based learning media carried out independently or in groups by students. Learning that is carried out independently or in groups, requires students to: (1) be responsible for completing all assignments given through student worksheets; (2) report the results of object-oriented programming practicum based on data or information honestly; and (3) show disciplinary behavior using practical clothing according to RPL's expertise study program when practicing objectoriented programming.

\section{Psychomotor learning outcomes for students who learn using virtual reality-based learning media are significantly higher than students who learn using power point.}

Psychomotor domains of learning outcomes indicators on object-oriented programming subjects are as follows: (1) preparing tools and materials according to procedures before starting virtual realitybased learning media; (2) able to choose the appropriate material; (3) plan work processes in sequence; (4) controlling computer equipment in accordance with their functions; (5) able to install materials properly; (6) designing object-based programming applications according to programming algorithms; (7) can manage the materials needed; (8) programming according to work steps; (9) able to analyze programming algorithms according to existing theories; (10) able to work to follow existing work safety regulations; (11) using tools skillfully and carefully; (12) able to complete the work within the time provided; (13) able to analyze work with the right procedure; (14) cleaning the workplace after use; (15) the results of the work function perfectly; (16) implementation in accordance with the original plan; (17) how the application works as expected; (18) the results of the application run well; (19) analyze the work of the application by running and understanding the algorithm; and (20) the results of the application work analysis are correct and correct.This can be seen from the significance level of the One Way Anava test for psychomotor domain learning outcomes of $0,000<0,05$. Through this research, it was found that students were able to: (1) prepare tools and materials according to the procedure before starting virtual reality based learning media; (2) able to choose the appropriate material; (3) plan work processes in sequence; (4) controlling computer equipment in accordance with their functions; (5) able to install materials properly; (6) designing object-based programming applications according to programming algorithms; (7) can manage the materials needed; (8) programming according to work steps; (9) able to analyze programming algorithms according to existing theories; (10) able to work to follow existing work safety regulations; (11) using tools skillfully and carefully; (12) able to complete the work within the time 
provided; (13) able to analyze work with the right procedure; (14) cleaning the workplace after use; (15) the results of the work function perfectly; (16) implementation of a matter

The results of this study are in line with the results of Sutanaya, Arthana and Wirawan (2017) research entitled "Development of Virtual Reality Vehicle Recognition for Early Childhood", which concluded that using virtual reality media the introduction of vehicles for early childhood can be played using a cardboard so that children children can interact with virtual reality environments. The results of this study are also in line with the results of research conducted by Dinis, Guimaraes, Carvalho and Martins (2017) with the title "Development of Virtual Reality Game-Based Interfaces for Civil Engineering Education", which concluded that using virtual reality is a relevant asset for civil engineering case studies, from various age groups and academic / professional backgrounds, so they can interact like civil engineering.

The results of this study are also in line with the theories that state that virtual reality-based learning media can improve student learning outcomes that include learning outcomes in the cognitive, affective, and psychomotor domains. Virtual reality based learning media can be accessed using a smartphone cellphone, so it can improve student learning outcomes. Especially on the subjects of object oriented programming. In addition learning through virtual reality based learning media makes it easier for teachers to explain basic concept material.

The findings of the psychomotor domain of student learning outcomes can be caused by: (1) XI RPL students in Bangkalan 2 Vocational High School are more interested in learning delivered through 3D animation, 3D simulation, and audio, so students have a high interest in implementing the psychomotor learning process; (2) virtual reality-based learning media can be accessed repeatedly according to students' ability to absorb material; (3) virtual reality-based learning media created in the form of material illustrations on basic concepts in the form of 3D animation and 3D simulations that make students feel the virtual world; and (4) virtual reality based learning media installed on a smartphone can be accessed by students anytime and anywhere.

\section{Students respond to virtual reality based learning media}

Based on the questionnaire obtained responses of class XI RPL-1 students to VR media, with details as many as 28 students stated strongly agree that VR media is used in learning, and the remaining 2 students agreed that VR media was used in the learning process on object oriented programming subjects with basic concept material.

The results of this study are in line with the results of research by Manouchou, Stavroulia, Harisiou, Georgiou, Sella, and Lanitis (2016) with the title "A Feasibility Study on Using Virtual Reality for Understanding Deficiencies of High School Students", concluding that another significant insight is that the participants were able to empathize with virtual students and feel the same emotions in students with myopia problems. Other research findings that are in line are the results of research by Sutanaya, Arthana and Wirawan (2017) with the title "Development of Virtual Reality Vehicle Recognition for Early Childhood", which concluded that the user response to virtual reality applications about the introduction of vehicles for early childhood included excellent categories ( with a percentage of 80\%).

The results of this study are also in line with the theories about students' responses to virual reality-based media on the subjects of object-oriented programming. Student response is a picture of the reactions that arise from the learning done by the teacher. The teacher is one element that influences the response that arises from students. Positive responses can arise if the teacher can attract students' attention by applying interesting virtual reality based learning media so that students can interact with the media. Various ways can be done, for example by providing material, quizzes, rewards, discussion forums, chat, or presenting interesting and different concepts than usual. Positive student responses can be seen from effective and conducive learning activities.The findings of student responses to virtual reality-based learning media can be caused by: (1) virtual reality-based learning media capable of motivating student learning; (2) learning media based on virtual reality are able to give effectiveness to learning media and students are more interactive; and (3) virtual reality-based learning media are able to provide active discussion between fellow students and teachers and make students able to answer teacher questions.

\section{CONCLUSION}


Based on the results of the discussions that have been conducted, the following conclusions can be drawn: (1) virtual reality based learning media on object oriented programming subjects are declared valid (average score of 3.52) so that they can be categorized very well; (2) the implementation of virtual reality based learning media on object-oriented programming subjects in basic concept material using direct learning models including good categories (mean score 3.66); (3) the response of students in SMK 2 Bangkalan to learning media based on virtual reality on object oriented programming subjects is very enthusiastic and agrees that virtual reality based learning media are used in learning; (4) learning activities of Bangkalan 2 Vocational High School students on object oriented programming subjects using virtual reality-based learning media can be said that all students are active in participating in learning activities; (5) cognitive, affective and psychomotor domains of learning outcomes for students who study using virtual reality-based learning media, significantly higher than students who learn using power point learning media.

\section{Implications}

The implications of this study are as follows: (1) in order to provide validity for good virtual reality-based learning media, teachers must be able to create virtual reality applications; (2) so that learning media can be implemented properly, teachers must implement learning media with appropriate learning tools.

\section{Suggestion}

Based on the results of the research that has been carried out the following suggestions are conveyed: (1) further research is needed on virtual reality-based learning media that can display the syntax of object-oriented programming so that it can generate computational thinking; (2) to implement virtual reality-based learning media, students need to be given more adequate preparation, especially in the use of VR Box tools, so that they do not encounter obstacles in their operation.

\section{REFERENCES}

[1] Trianto. (2011). Model Pembelajaran Terpadu Konsep, Strategi Dan Implementasinya Dalam Kurikulum Tingkat Satuan Pendidikan (KTSP). Jakarta, Indonesia: Bumi Aksara.

[2] Prawiradilaga, D. S. (2012). Wawasan Teknologi Pendidikan. Jakarta, Indonesia: Kencana Prenada Media Group.

[3] Alwi, S.: Manajemen Sumber Daya Manusia, Strategi Keunggulan Kompetitif. Yogyakarta, Indonesia: Badan Penerbit Fakultas Ekonomi.(2001).

[4] Psotka, J. (1995). Immersive Training Systems: Virtual Reality and Education and Training. Education Resources Information Center (ERIC). ISSN-0020-4277.

[5]Daryanto. (2012). Media Pembelajaran. Bandung, Indonesia: Sarana Tutorial Nurani Sejahtera.

[6] Arsyad, A. (2014). Media Pembelajaran. Jakarta, Indonesia: PT Rajagrafindo Persada.

[7] Sadiman, A. (1984). Media Pendidikan. Jakarta, Indonesia: PT Raja Grafindo Persada.

[8] Ibrahim, H., Sihkabuden, S., \& Kustiawan, U. (2001). Media Pembelajaran: Bahan Sajian Program Pendidikan Akta Mengajar. Malang, Indonesia FIP-UM.

[9] Hamalik, O. (2013). Kurikulum dan Pembelajaran. Jakarta, Indonesia: Bumi Aksara.

[10] Purwanto. (2013). Evaluasi Hasil Belajar. Yogyakarta, Indonesia: Pustaka Belajar.

[11] Dimyati., \& Mudjiono. (2006). Belajar dan Pembelajaran. Jakata, Indonesia: Rineka Cipta.

[12] Uno, H. B. (2011). Model Pembelajaran;Menciptakan Proses Belajar Mengajar yang Kreatif dan Efektif. Jakarta, Indonesia: Bumi Aksara.

[13] Liu, C. (2012). Using Virtual Reality to Improve Design Communication. Calgary, Canada: University of Calgary.

[14] Zhang, L., \& Zheng, G. (2011). The Virtual Campus Scene Based on VRML. Journal Institute of Electrical and Electronics Engineers (IEEE). 912-915. doi 10.1109/ICMT.2011.6001891.

[15] Widhiartha, P. A. (2007). Ubiquitous Computing - Era Ketiga dari Revolusi Komputer. Bogor, Indonesia: IlmuKompuer.

[16] Kurniadi, A. (1999). Membuat Dunia 3D dengan VRML. Jakarta, Indonesia: PT Elex Media Komputindo. 
[17] Borg, W. R., \& Gall, M. D. (1989). Educational Research: An Introduction, Fifth Edition. NewYork, US: Longman.

[18] Sugiyono. (2013). Metode Penelitian Kuantitatif, Kualitatif dan R\&D. Bandung, Indonesia: Alfabeta.

[19] Furchan, A. (1982). Pengantar Penelitian dalam Pendidikan. Surabaya, Indonesia: Usaha Nasional.

[20] Ratumanan, T, G. (2006). Evaluasi Hasil Belajar yang relevan dengan Kurikulum Berbasis Kompetensi. Surabaya, Indonesia: Unesa University Press.

[21] Arikunto, S. (2012). Dasar-Dasar Evaluasi Pendidikan. Jakarta, Indonesia: Bumi Aksara.

[22] Depdiknas. (2005). Panduan Pengembangan Model Pembelajaran Berbasis Kompetensi. Jakarta, Indonesia: Direktorat PPTK dan KPT Dirjen Dikti.

[23] Sugihartono., Fatiyah, K. R., Setiawati, F. A., Harahap, F., \& Nurhayati, S. R. (2007). Psikologi Pendidikan. Yogyakarta, Indonesia: UNY Press.

[24] Sukintaka. (2001). Teori Pendidikan Jasmani. Yogyakarta, Indonesia: Yayasan Nuansa Cendikia.

[25] Sarwono, S. (1995). Psikologi Lingkungan. Jakarta, Indonesia: Grasindo.

[26] Azwar, S. (1988). Sikap Manusia, Teori, dan Pengukurannya. Seri psikologi. Yogyakarta, Indonesia: Liberty.

[27] Suprihatiningrum, J. (2013). Strategi Pembelajaran. Jogjakarta, Indonesia: Ar-Ruzz Media.

[28] Sardiman, A. M. (2000). Interaksi dan Motivasi Belajar Mengajar. Jakarta, Indonesia: PT Raja Grafindo Persada.

[29] Widhiartha, P. A. (2007). Ubiquitous Computing - Era Ketiga dari Revolusi Komputer. Bogor, Indonesia: IlmuKompuer. 